\title{
ИСТОРИЯ И СОВРЕМЕННОЕ СОСТОЯНИЕ ЗЕЛЕНЫХ НАСАЖДЕНИЙ ПОСЕЛКА КОКТЕБЕЛЬ
}

\author{
Потапенко И.Л. \\ ФГБУН «Карадагская научная станция им. Т.И. Вяземского - природный заповедник РАН», \\ 2. Феодосия, Российская Федераџия, E-mail: ira_potapenko@mail.ru
}

Приводится список декоративных древесных растений, используемых в различных объектах зеленого строительства поселка Коктебель, изучена история их формирования. Особое внимание уделено паркам крупных рекреационных комплексов. Предложены пути оптимизации зеленых насаждений различного функционального назначения.

Ключевые слова: декоративные древесные растения, перспективы озеленения, поселок Коктебель, Юго-Восточный Крым.

\section{Введение}

Поселок Коктебель - один из самых известных и посещаемых курортов Юговосточного Крыма. Он занимает особое место не только в истории и культуре Крыма, но также играет значительную роль в развитии русской науки, литературы и искусства. В начале XX в. Коктебель стал своеобразной меккой художников, писателей, поэтов, композиторов, ученых, литературоведов, других представителей науки и культуры. Здесь гостили художники: К.Ф. Богаевский, Л.А. Бруни, Е.С. Кругликова, А.П. ОстроумоваЛебедева, К.С. Петров-Водкин, Р.Р. Фальк; писатели и поэты: Андрей Белый (Б.Н. Бугаев), В.Я. Брюсов, В.В. Вересаев, Р.М. Гинцбург, Н.С. Гумилев, В.М. Инбер, К.Г. Паустовский, А.И. и М.И. Цветаевы; ученые: А.А. Байков (русский, советский химик и металлург, действительный член и вице-президент АН СССР), А.С. Башкиров (археолог, крымовед), С.И. Златогоров (микробиолог, эпидемиолог, инфекционист, член-корр. АН СССР), C.В. Лебедев (химик, академик АН СССР), В.Д. Шервинский (врач, один из основоположников эндокринологии в России) и др. Коктебель также посещали известные искусствоведы, литературные критики, переводчики, музыканты, философы, архитекторы, композиторы. Особое место занимает Коктебель в истории отечественного планеризма и воздухоплавания, в связи с чем поселок с 1944 по 1992 гг. носил имя Планерское. С начала прошлого века Коктебель начинает быстро развиваться как курорт. Это связывают со строительством в Феодосии торгового порта и железной дороги, проходящей по берегу моря, что в значительной мере негативно повлияло на использование ее как приморского курорта. Привлекательными курортологическими ресурсами Коктебеля являются наличие моря, гористого рельефа, достаточное поступление солнечной энергии и т. п. Его расположение также считается подходящим для детского курорта (Лесина, 1980; Владимиров, Костенко, 1997; Жарков, 2008). В последние десятилетия хаотичная застройка поселка, отсутствие современной канализации, резко возросшее количество автомобилей на его территории и другие антропогенные воздействия значительно снизили его ценность как здравницы и культурно-исторического объекта.

Одним из важнейших факторов оздоровления климата любого населенного пункта является рациональное озеленение его территории. Необходимо признать, что в настоящее время формированию здоровой среды городов и поселков не уделяется должного внимания. Тогда как, в СССР, например, научно-исследовательские институты соответствующего профиля, учреждения здравоохранения, органы, ведающие благоустройством населенных пунктов, серьезно занимались данными вопросами, чему посвящено большое количество 
работ (Лунц, 1966; Кучерявый, 1981; Кохно и др., 1983; Гостев, Юскевич, 1991 и др.). Поэтому в настоящее время кроме решения ряда экологических и технологических проблем необходимо осуществлять научно обоснованное зеленое строительство в регионе. Учеными на протяжении ряда лет проводятся исследования зеленых насаждений городов и поселков Крыма (Потемкина, Романенко, 2011; Колосюк, Савушкина, 2014; Потапенко и др., 2014; Улейская и др., 2014; Репецкая, Парфенов, 2015; Потемкина, Шевчук, 2015 и др.), что позволяет надеяться на дальнейшее развитие совместных действий органов власти и различных специалистов по созданию благоприятной комфортной среды для жизни и отдыха на полуострове. Исследование истории формирования и современного состояния культивированной дендрофлоры и растительности Коктебеля позволит наиболее правильным образом определить пути развития здесь научно обоснованного зеленого строительства.

Цель работы - разработка путей оптимального озеленения поселка Коктебель на основании литературных данных, собственных исследований и опыта культивирования здесь декоративных древесных растений.

\section{Материалы и методы}

Исследования проводились на территории поселка Коктебель с 2000 г. Обследовались парки домов отдыха, пансионатов, детских оздоровительных комплексов, уличные насаждения, небольшие зеленые зоны вокруг общественных зданий. При этом определялись следующие показатели: вид (разновидность, гибрид, форма), количество экземпляров и их местопроизрастание; возраст и биологические особенности; экологическая характеристика (засухоустойчивость - стойкость к летней засухе, морозо- и зимостойкость, ветроустойчивость, стойкость к влиянию моря). Изучалась также декоративность растений и способы их использования в парковых сообществах и иных зеленых насаждениях. Декоративность оценивалась по следующим параметрам: структура и форма кроны, обильность цветения и его эстетический эффект, форма, фактура и осенняя окраска листьев, своеобразная форма и окраска плодов.

В 2016 г. мы вновь обследовали зеленые насаждения поселка для получения современных данных об их состоянии. Основными объектами зеленого строительства Коктебеля в настоящее время являются: базы отдыха «Голубой залив» (6 га), «Якорь» ( 4 га); туристическо-оздоровительный спортивный комплекс «Приморье» $(3,5$ га), база отдыха «Прибой» ( 2 га). Мы также приводим данные о зеленых насаждениях детских оздоровительных комплексах «Восход» $(7,0$ га) и «Горный» $(1,7$ га), которые в настоящее время не функционируют. В работе нами также приводятся сведения о парке Литфонда, который к настоящему моменту прекратил свое существование, однако ранее был одним из самых лучших парков Юго-Восточного Крыма.

Сведения о развитии зеленого строительства в исследуемом районе были получены из литературных источников, приводимых в тексте, и архивных материалов. Некоторые данные уточнялись у местных краеведов и старожилов.

В таблице графа «Коктебель» содержит данные об уличном озеленении, а также деревьях и кустарниках, произрастающих у общественных зданий: школы, дома культуры и т. п. Нами не проводились определения форм и сортов садовых роз, поэтому в таблице приводятся лишь сведения об их наличии.

Определение таксономического состава проводилось как в полевых условиях, так и на основании собранного гербарного материала. Видовая принадлежность деревьев и кустарников принята по С.К. Черепанову (1995) и А.В. Ене (2012). 


\section{Результаты и обсуждение}

Современный Коктебель сложился на основе болгарского села Коктебель и хутора Бараколь, русского хутора Кордон, греческого хутора Арматлук, и дачного поселка на берегу залива. Еще болгары высаживали акацию (Robinia pseudoacacia L.) для озеленения села вдоль Судакского шоссе; тополь пирамидальный (Populus italica (Du Roi) Moench) вдоль дорог; дерезу (Lycium barbarum L.) - для создания живой изгороди вокруг домов; широко культивировали миндаль (Prunus duclis (Mill.) D.A. Webb) во дворах, вдоль дорог, на высокогорных виноградниках. Основателем дачного Коктебеля по праву считается Э.А. Юнге (1833-1898) - академик, окулист-офтальмолог. В конце 70-х гг. ХІХ в. он скупил значительную часть долины, прилегающую к морю и решил превратить ее в сад. Выйдя в отставку в 1882 г., с увлечением занялся благоустройством своего коктебельского поместья, виноградарством, виноделием. В его доме часто гостили литераторы, художники, деятели науки и культуры. Испытывая денежные затруднения (особенно для мелиоративных работ), семья Юнге приняла решение распродать наиболее бесплодную часть своих обширных владений, прилегающих к пляжу, частным лицам для дачного строительства. Эдуард Андреевич надеялся, что подобно колонистам Запада дачники обживут и цивилизуют пустынную Коктебельскую приморскую равнину. После его смерти наследники распродали участки у моря. Их владельцами стали представители мелкопоместного дворянства, феодосийского уездного мещанства и киевских церковных кругов. Одной из первых купила участок у моря Е.О. Кириенко-Волошина - мать художника и поэта М.А. Волошина. Их соседями стали известные литераторы, художники, музыканты. Некоторые из них увлекались созданием небольших садиков в своих усадьбах и даже привозили для них растения из-за границы. Так в дачном Коктебеле росли: айлант (Ailanthus altissima (Mill.) Swingle), барбарис (Berberis thunbergii DC.) девичий виноград (Parthenocissus quinquefolia (L.) Planch.), кипарис вечнозеленый (Cupressus sempervirens L.), клен татарский (Асеr tataricum L.), софора японская (Styphnolobium japonicum (L.) Schott), которая использовалась, в том числе, и как лекарственное растение. В архиве А.П. Новицкого (искусствовед) сохранилось много документов по благоустройству своей коктебельской усадьбы. Среди них - договор на сооружение колодца и подробный список деревьев и кустарников для посадки. Многие также делали добровольные пожертвования на обустройство поселка. Так была реализована идея Юнге о «цивилизации» усилиями дачников Коктебеля, который уже в начале XX в. был известен как модный курорт (Шапошников, 1999; Левичев, Тимиргазин, 2003; Фадеева, Шапошников, Дидуленко, 2004). Таким образом, дачи и усадьбы представителей творческой интеллигенции, мелкопоместного дворянства и государственных чиновников в начале прошлого века стали центрами интродукционной деятельности (в основном, стихийной), положившей начало зеленому строительству в Коктебеле.

С конца двадцатых годов прошлого века началась компания по конфискации дачных домов у моря и передача их различным государственным, профсоюзным и кооперативным организациям, которые использовали их для отдыха и оздоровления трудящихся. В 30-е гг. Коктебель - небольшой приморский курорт, имеющий 7 домов отдыха (Московского горкома Союза писателей, Ленинградского горкома Союза писателей, Военной академии механизации и моторизации и др.), но еще не совсем благоустроенный: нет хорошей воды, парка, общедоступных зрелищ и других удобств (Левичев, Тимиргазин, 2003). Еще в начале прошлого века писатель и мемуарист С.Я. Елпатьевский писал: «В Коктебели нет общественного сада, нет «музыки» садовой <..>. Там не растет настоящей травы, а только что-то сухое и корявое, <...> садики, которые дачники из всех сил разводят около своих маленьких домиков, <... . <..> коктебельские деревья так медленно растут и так часто засыхают. <..> Может быть, розовые аллеи, и большие парки, и пышные цветники не подходили бы к Коктебели, спутали бы их, затушевали линии и краски Коктебели» (Елпатьевский, 1998). Отсутствие хорошей воды и, как следствие, отсутствие зеленых 
насаждений так и оставались основными недостатками курортного Коктебеля довоенного времени. Развитие садов и парков здесь стало возможным только с появлением водопровода (50-е гг. XX в.). К советскому периоду начала 50-х - конца 80-х гг. следует отнести расцвет зеленого строительства в Коктебеле. Именно в это время были созданы замечательные парки, приуроченные к крупным рекреационным комплексам: Дом творчества Союза советских писателей, «Голубой залив», «Приморье» и др., информация о которых приводится ниже.

Современный Коктебель озеленен недостаточно, примитивно, хаотично, деревья и кустарники подобраны без учета специфики климата, местности, функционального назначения. Вероятно, озеленение осуществлялось стихийно, без научного сопровождения и привлечения каких-либо специалистов ландшафтного дизайна. Здесь нет общественных парков, скверов, пешеходных аллей, лишь небольшие зеленые зоны вокруг общественных зданий: школы, дома культуры и т. п.; уличное озеленение практически отсутствует. Хотя видовое и формовое разнообразие древесной флоры в Коктебеле выше, чем в других населенных пунктах Юго-Восточного Крыма (Потапенко, Кузнецов, 2009). Из древесных растений, произрастающих на улицах поселка, можно отметить те, которые экологически и физиономически соответствуют южному колориту местности: платаны (начало ул. Ленина, территория школы), кипарисы аризонские (фрагментами по ул. Ленина), несколько деревьев клена татарского (возле магазина «Коктебель» по ул. Ленина), небольшая группа из сосны пицундской и можжевельника виргинского в пер. Горном. Всего на территории поселка нами зарегистрировано 169 видов и форм деревьев и кустарников (табл.). Основными объектами зеленого строительства Коктебеля являются древесные насаждения рекреационных комплексов.

\section{Турбаза «Приморье».}

Турбаза «Приморье» размещается на обширных землях бывшего имения Павловых, которые в начале XX в. были одними из наиболее крупных землевладельцев в Коктебеле. Во время войны дом и флигель имения были взорваны (Жарков, 2008). Строительство пансионата, впоследствии преобразованного в туристскую базу «Приморье», началось в 1956 г. Первоначально туристы размещались в палаточных городках и небольших домиках. «Трудно было тогда представить, что пройдет немного времени и на голом месте поднимутся вечнозеленые деревья, раскинутся пестрыми коврами многочисленные цветники», - написано о первых годах функционирования здравницы (Петков, 1979). В 6070-е гг. турбаза превратилась в крупное оздоровительное учреждение Юго-Восточного Крыма, которое работало круглый год, принимая на оздоровление и отдых трудящихся со всего Советского Союза. Здесь функционировали спортивные площадки, медпункт, летний и зимний кинотеатры, библиотека. Через «Приморье» проходили пути туристов шести всесоюзных маршрутов по Крыму. С 1977 г. турбаза начала обслуживать родителей с детьми школьного возраста. Как уже отмечалось ранее, озеленение территории проходило одновременно со строительством здравницы. Здесь высаживались ясени (Fraxinus angustifolia Vahl., F. pensilvanica March. и др.), вяз (Ulmus pumila L.), лох (Elaeagnus angustifolia L.), сосна (Pinus brutia var. pityusa (Steven) Silba) и др.

В настоящее время турбаза «Приморье» - один из немногих рекреационных комплексов региона, сохранивший свою целостность, избежавший хаотичной застройки в последние десятилетия. Современная территория изобилует разнообразными экзотическими деревьями и кустарниками (88 видов и форм), коллекция которых постоянно пополняется. Ухаживает за насаждениями мастер зеленого хозяйства, агроном Акуленко Т.И. Профессиональный подход чувствуется во всем: рациональный выбор ассортимента, надлежащий уход за растениями с учетом их биологических особенностей и экологических требований, интересный ландшафтный дизайн. Здесь есть стилизованный терренкур с цветочным оформлением; небольшой водоем, круженный различными формами 
можжевельника казацкого; каскад из самшита (Buxus sempervirens L.), магонии (Mahonia aquifolium (Pursh) Nutt.), калины (Viburnum lantana L.), бобовника (Laburnum anagyroides Medik.) и даже лабиринт из самшита. Декоративные деревья и кустарники в сочетании с многочисленными газонами, клумбами, каменистыми горками, цветниками создают позитивное настроение, ощущение отдыха, релакса.

\section{Пансионат «Голубой залив».}

Начало истории пансионата «Голубой залив» положил санаторий Медсантруда (Управление санаториями и домами отдыха Центрального Комитета Союза медикосанитарного труда), организованный в июне 1946 г. Первыми зданиями для пансионата послужили 2 довоенных дома - 1920 г. и 1937 г. постройки (предположительно, бывшие дачи - одна из них некоторое время принадлежала писателю В.В. Вересаеву). К 1948 г. были построены 2 новых корпуса, столовая, клуб, другие хозяйственные объекты, что позволило принять первых отдыхающих уже в августе этого года. С годами здравница развивалась, строилась и выросла в одну из самых крупных на юго-восточном берегу Крыма. С 1978 г. пансионат одним из первых в Союзе принимает на отдых родителей с детьми. За высокую организацию семейного отдыха пансионат неоднократно отмечался дипломами, грамотами, премиями (Лесина, 1980).

Современная территория пансионата разделена на две части улицей Ленина. В приморской (левой) части расположены корпуса, столовая, бассейн, хозяйственные постройки и т. п. Зеленые насаждения здесь имеют «современный» вид: много молодых деревьев, которые сопровождаются цветочным оформлением, «горками», небольшими газонами. Правая часть - более старая, деревья и кустарники здесь ориентировочно 60-70х гг. посадки. Основу насаждений составляют: Elaeagnus angustifolia L., Platycladus orientalis 'Globosa', Pinus brutia var. pityusa (Steven) Silba, Populus alba L., Tamarix tetrandra Pall. ex M. Bieb. Единично отмечены такие декоративные деревья, как Fraxinus syriaca Boiss., Morus alba 'Pendula', Gleditschia triacanthos L. В настоящее время эта территория имеет довольно запущенный вид, однако именно она после незначительного «облагораживания» может стать местом отдыха, поскольку деревья создают здесь приятную тень, спасают от жары и зноя в летний период.

\section{База отдыха «Якорь».}

База отдыха «Якорь» расположена в северной части поселка Коктебель и занимает территорию около 4 га. По сведениям сотрудников, она была построена в конце 70-х гг. прошлого века, тогда же на ее территории проводились озеленительные работы. Следовательно, примерный возраст основной массы деревьев и кустарников, произрастающих здесь, составляет 35-40 лет. Их видовой и формовой состав достаточно разнообразен (59 видов и форм). Здесь растут декоративные деревья и кустарники, которые редко встречаются в других местах Коктебеля: Koelreuteria paniculata Laxm., Laurocerasus officinalis M.Roem., Lonicera caprifolium L., L. maackii Rupr, Punica granatum L. Sorbus torminalis (L.) Crantz, Tilia dasystila Steven, Viburnum tinus L. Возле главного корпуса растут две магнолии (Magnolia grandiflora L.) - красивоцветущие вечнозеленые деревья, которые вообще редки для парков Юго-Восточного Крыма, т.к. вымерзают здесь в холодные зимы. В «Якоре» есть спортивные и детские площадки, хорошо продуманы зоны отдыха. Детские площадки оформлены зеленой изгородью из форзиции (Forsythia x intermedia Zab.) и спиреи (Spiraea x vanhouttei (Briot) Zab.), для зон отдыха используются элементы вертикального озеленения с камсисом (Campsis radicans (L.) Seem.) и виноградом (Vitis vinifera L.). Необходимо отметить, что практически все саженцы деревьев и кустарников покупались в питомниках Феодосийского района, поэтому они адаптированы к местным условиям. Этим фактом и надлежащим уходом объясняется хорошее состояние растений в «Якоре». 


\section{Дом творчества писателей «Коктебель».}

Дом творчества писателей неразрывно связан с именем поэта, художника, литературного критика, философа М.А. Волошина (1877-1932), который в мае 1931 г. завещал свою усадьбу Союзу писателей РСФСР «для устройства Дома отдыха для писателей, под именем Дом поэта», как указывалось в завещании. Во исполнение дарственной уже в августе этого же года в Дом поэта приехала первая группа писателей для работы и отдыха. Так начал свою жизнь первый в стране Дом творчества, получивший название «Коктебель». Союз писателей СССР не жалел средств на содержание и развитие Дома творчества, создавая благоприятную атмосферу для труда и отдыха. «В зелени прекрасного парка прячутся уютные коттеджи и двухэтажные дома с балконами-лоджиями, откуда открывается вид на море или горную цепь Карадага», - так написано в путеводителе по Коктебелю (Лесина, 1980). Первые посадки деревьев и кустарников вокруг Дома поэта были сделаны еще М.А. Волошиным и его матерью. В последующие годы парк развивается, расширяется его территория, высаживается большое количество декоративных деревьев и кустарников. Наряду с цветочным оформлением и вечнозелеными кустарниками уже в 30-е гг. прошлого века в парке Литфонда растут такие экзотические для Юго-Восточного Крыма растения, как пальмы (Trachycarpus fortunei (Hook.) H. Wendl., Chamaerops humilis L.), придавая ему неповторимый южный колорит. С 50-х годов прошлого века в Доме творчества работал садовником С.А. Клименко, под руководством которого проводились все парковые работы. С.А. Клименко - автор более двадцати сортов роз (среди них «Коктебель», «Карадаг», «Поэзия»). В 60-70-е годы XX в. Литфонд неоднократно отмечается наградами за лучшую организацию территории. Парк здесь действительно восхищал всех посетителей. Его растения и планировка гармонично вписывались в природный ландшафт, создавая единый ансамбль. Деревья и кустарники, произрастающие в нем: кедры, кипарисы, можжевельники и др. оказывали благоприятное эмоциональное, эстетическое и лечебное воздействие на человека (Лесина, 1980; Танасийчук, 1983; Владимиров, Костенко, 1997; Купченко, 2002; Фадеева, Шапошников, Дидуленко, 2008).

С середины 90-х гг. в связи с общими негативными политическими и экономическими процессами начинается раздел, продажа, а фактически, уничтожение, как самой здравницы, так и ее прекрасного парка. Однако еще в начале 2000-х годов в парке насчитывалось более 80 видов и форм древесных растений. Особенно красивыми были атласские кедры и его декоративные формы (Cedrus atlantica Manetti, C. a. 'Argentea', C. a. 'Breviramulosa'), ливанский кедр (Cedrus libani A. Rich.), кипарисы аризонские и его формы (Cupressus arizonica Greene, C. a. var. glabra (Sudw.) Little, C. $a$. 'Truncis pluribus'), тисс ягодный и его пирамидальная форма (Taxus baccata L., T. b. 'Stricta'), пихты (Abies numidica De Lannoy). Здесь росли редкие для Юго-Восточного Крыма вечнозеленые деревья и кустарники (Quercus ilex L., Aucuba japonica 'Variegata', Berberis julianae Schneid., Buxus balearica Lam., Viburnum rhytidophyllum Hemsl., V. tinus L.) и листопадные деревья (Broussonetia papyrifera (L.) Vent., Fraxinus excelsior 'Pendula', Robinia hispida L., R. viscose Vent., Styphnolobium japonicum 'Pendula', Zelkova carpinifolia (Pall.) C. Koch). Некоторые из этих растений сохранились. В настоящее время Дом творчества прекратил свое существование, его территория полностью разделена на части и застроена, от парка остались отдельные деревья и кустарники, не требующие ухода, но назвать парком данные образования не представляется возможным. Остается надеяться, что после вхождения Крыма в состав Российской Федерации Дом творчества писателей будет возрожден, а вместе с ним будет вновь создан парк, красота которого дополнит неизменное очарование Коктебеля. 
Таблица

Декоративные деревья и кустарники пос. Коктебель

\begin{tabular}{|c|c|c|c|c|c|c|c|c|}
\hline $\begin{array}{l}\text { № } \\
\text { пा }\end{array}$ & Вид & 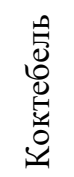 & 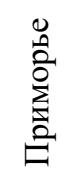 & 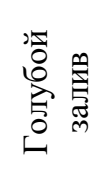 & 谷 & 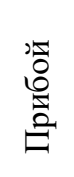 & 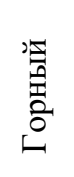 & $\begin{array}{l}F \\
0 \\
\dot{x} \\
0 \\
0 \\
0\end{array}$ \\
\hline 1 & 2 & 9 & 3 & 4 & 8 & 6 & 5 & 7 \\
\hline 1. & Abies pinsapo Boiss. & & + & & & & & \\
\hline 2. & A.p. 'Glauca' & & + & & & & & \\
\hline 3. & Acer campestre $\mathrm{L}$. & & & & & + & & \\
\hline 4. & A. negundo L. & + & & & & & & \\
\hline 5. & A. platanoides $\mathrm{L}$. & + & & & & & + & \\
\hline 6. & A.p. 'Variegatum' & & + & & & & & \\
\hline 7. & A. pseudoplatanus $\mathrm{L}$. & & & + & + & & & \\
\hline 8. & A. saccharinum L. & + & & & & & & \\
\hline 9. & A. tataricum $\mathrm{L}$. & + & & & & & & \\
\hline 10. & Aesculus hippocastanum L. & + & + & + & + & & + & \\
\hline 11. & $\begin{array}{l}\text { Ailanthus altissima (Mill.) } \\
\text { Swingle }\end{array}$ & + & + & + & + & + & & \\
\hline 12. & Albizzia julibrissin Durazz. & + & + & & + & & & \\
\hline 13. & $\begin{array}{l}\text { Berberis thunbergii } \\
\text { 'Atropurpurea' }\end{array}$ & & + & & & & & \\
\hline 14. & Betula pendula Roth & + & + & & + & & + & \\
\hline 15. & Buxus balearica Lam. & & + & . & & & & \\
\hline 16. & B. sempervirens $\mathrm{L}$. & + & + & + & + & & + & \\
\hline 17. & Campsis radicans (L.) Seem. & + & + & + & + & & & \\
\hline 18. & $\begin{array}{l}\text { Caragana arborescens } \\
\text { 'Pendula' }\end{array}$ & & + & & & & & \\
\hline 19. & Catalpa speciosa Ward. & + & + & & & & & \\
\hline 20. & Cedrus atlantica Manetti & + & + & + & + & + & & \\
\hline 21. & C. a. 'Glauca' & + & + & + & + & & & \\
\hline 22. & C. deodara (D. Don) G.Don f. & + & + & & & & & \\
\hline 23. & C. libani A. Rich. & + & + & & & + & & \\
\hline 24. & Cercis siliquastrum L. & + & + & + & & & & \\
\hline 25. & $\begin{array}{l}\text { Chaenomeles japonica (Thunb.) } \\
\text { Lindl. }\end{array}$ & + & + & & & & & \\
\hline 26. & Ch. speciosa (Sweet) Nakai & + & & + & & & & \\
\hline 27. & $\begin{array}{l}\text { Chamaecyperis lawsoniana } \\
\text { (A.Murray) Parl. }\end{array}$ & & + & & & & & \\
\hline 28. & $\begin{array}{l}\text { Clematis jackmanii Th. Moore } \\
\text { (сорта) }\end{array}$ & & + & & & & & \\
\hline 29. & C. vitalba $\mathrm{L}$. & + & & & & & & + \\
\hline 30. & Cotinus coggygria Scop. & + & & & & & & \\
\hline 31. & $\begin{array}{l}\text { Cotoneaster buxifolius Wallich } \\
\text { ex Lindley }\end{array}$ & + & + & & & & & \\
\hline 32. & C. horizontalis Decaisne & & & + & & & & \\
\hline 33. & C. salicifolius Franchet & + & & & & & & \\
\hline 34. & C. tauricus Pojark. & & & & & + & & \\
\hline 35. & $\begin{array}{l}\text { Crataegus rhipidophylla } \\
\text { Gandoger (C. curvisepala } \\
\text { Lindm.) }\end{array}$ & & & & & + & & + \\
\hline 36. & C. monogyna Jacq. & & & & & + & & + \\
\hline 37. & C. orientalis Pall. ex M. Bieb. & & & & & + & & + \\
\hline 38. & $\begin{array}{l}\text { Crataegus pallasii Griseb. }(=C . \\
\text { stevenii Pojark.) }\end{array}$ & & & & & & & + \\
\hline
\end{tabular}


продолжение табл.

\begin{tabular}{|c|c|c|c|c|c|c|c|c|}
\hline 39. & Cupressus arizonica Greene & + & + & + & & & + & \\
\hline 40. & $\begin{array}{l}\text { C. arizonica var. glabra (Sudw.) } \\
\text { Little }\end{array}$ & + & & & & & & \\
\hline 41. & C. arizonica `Truncis pluribus` & + & & & & & & \\
\hline 42. & C. sempervirens $\mathrm{L}$. & + & + & + & + & & + & + \\
\hline 43. & C.s. 'Australis' & + & + & + & & & & \\
\hline 44. & C.s. 'Densus' & + & & & & & & \\
\hline 45. & C.s. 'Indica' & + & & & & & & \\
\hline 46. & C.s. 'Pyramidalis' & + & + & + & + & + & & \\
\hline 47. & Cydonia oblonga Mill. & + & + & + & + & & & \\
\hline 48. & Elaeagnus angustifolia $\mathrm{L}$. & + & + & + & + & + & & + \\
\hline 49. & Euonymus japonica Thunb. & & + & & & & & \\
\hline 50. & Ficus carica $\mathrm{L}$. & & & & & & + & \\
\hline 51. & Forsythia $\mathrm{x}$ intermedia Zab. & + & 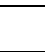 & + & + & & + & \\
\hline 52. & Fraxinus angustifolia Vahl. & + & + & + & + & & & \\
\hline 53. & F. excelsior L. & + & + & + & + & & + & + \\
\hline 54. & F. lanceolata Borkh. & + & + & + & + & & & \\
\hline 55. & F. pensilvanica March. & + & + & & + & & & \\
\hline 56. & Fraxinus syriaca Boiss. & + & + & . & & & & \\
\hline 57. & Gleditschia triacanthos L. & + & + & + & + & & + & \\
\hline 58. & Hedera helix $\mathrm{L}$. & + & + & + & & & & \\
\hline 59. & Hibiscus syriacus L. & + & + & + & + & & + & \\
\hline 60. & Jasminum nudiflorum Lindl. & & + & + & & & & \\
\hline 61. & Juglans regia $\mathrm{L}$. & + & & & + & & + & \\
\hline 62. & Juniperus communis $L$. & + & + & + & + & & + & \\
\hline 63. & Juniperus excelsa M. Bieb. & & + & & + & & & \\
\hline 64. & $\begin{array}{l}\text { J. deltoides R.P. Adams (J. } \\
\text { oxycedrus L.) }\end{array}$ & & & + & & & & \\
\hline 65. & J. sabina $\mathrm{L}$. & + & + & + & + & & & \\
\hline 66. & J.s. 'Variegata' & & + & & & & & \\
\hline 67. & J.s. 'Tamariscifolia' & & + & & & & & \\
\hline 68. & J. virginiana $\mathrm{L}$. & + & + & + & + & & & \\
\hline 69. & Kerria japonica 'Pleniflora` & & + & & & & & \\
\hline 70. & Koelreuteria paniculata Laxm. & & & & + & & & \\
\hline 71. & Laburnum anagyroides Medik. & + & + & & & & & \\
\hline 72. & Laurocerasus officinalis Roem. & & + & & + & & & \\
\hline 73. & Ligustrum lucidum Ait & + & & & & & & \\
\hline 74. & L. vulgare L. & + & + & + & + & & + & + \\
\hline 75. & Lonicera caprifolium L. & & & & + & & & \\
\hline 76. & L. fragrantissima Lindl. et Paxt. & + & + & + & & & & \\
\hline 77. & L. japonica Thunb. & + & + & & & & & \\
\hline 78. & L. maackii Rupr & + & & & + & & & \\
\hline 79. & L. tatarica $\mathrm{L}$. & & + & + & & + & + & \\
\hline 80. & Lycium barbatum $\mathrm{L}$. & + & & & & & & \\
\hline 81. & $\begin{array}{l}\text { Maclura pomifera (Raf.) } \\
\text { Schneid. }\end{array}$ & + & + & + & + & & & + \\
\hline 82. & Magnolia grandiflora L. & & & & + & & & \\
\hline 83. & $\begin{array}{l}\text { Mahonia aquifolium (Pursh) } \\
\text { Nutt. }\end{array}$ & + & + & + & & & & \\
\hline 84. & Malus domestica Borkh. & + & + & + & + & & & + \\
\hline 85. & M. niedzwetzkyana Dieck. & + & & & & & & \\
\hline 86. & M. x purpurea (Barbier) Rehd. & & & + & & & & \\
\hline
\end{tabular}


продолжение табл.

\begin{tabular}{|c|c|c|c|c|c|c|c|c|}
\hline 87. & Morus alba L. & + & & + & & & + & \\
\hline 88. & M. a. 'Pendula' & + & + & + & & & & \\
\hline 89. & M. nigra L. & + & & & & & + & \\
\hline 90. & $\begin{array}{l}\text { Opuntia camanchica Engelm.et } \\
\text { Bigel. }\end{array}$ & + & & & & & & \\
\hline 91. & O. humifusa Raf. & & & + & & & & \\
\hline 92. & Padus avium Mill. & + & & & & & & \\
\hline 93. & $\begin{array}{l}\text { Parthenocissus quinquefolia (L.) } \\
\text { Planch. }\end{array}$ & + & + & & & + & & \\
\hline 94. & $\begin{array}{l}\text { P. tricuspidata (Sieb. et Zuccs.) } \\
\text { Planch. f. veitchii (Graebn.) } \\
\text { Rehd. }\end{array}$ & & & & & & & + \\
\hline 95. & Philadelphus coronarius L. & + & + & + & & & & \\
\hline 96. & Picea abies (L.) Karst. & + & + & + & & & + & \\
\hline 97. & P. glauca 'Conica' & & + & & & & & \\
\hline 98. & P. pungens Engelm. & + & + & + & & & & \\
\hline 99. & P.p. 'Glauca' & + & + & + & + & + & + & \\
\hline 100. & $\begin{array}{l}\text { Pinus brutia var. pityusa } \\
\text { (Steven) Silba }\end{array}$ & + & + & + & + & & & \\
\hline 101. & P. mияо `Gnom` & & + & & & & & \\
\hline 102. & $\begin{array}{l}\text { P. nigra J.F. Arnold subsp. } \\
\text { pallasiana (Lamb.) Holmboe }\end{array}$ & + & + & + & + & + & + & + \\
\hline 103. & Platanus $\mathrm{x}$ acerifolia Willd. & + & & & & & & \\
\hline 104. & P. occidentalis L. & + & & & + & & & \\
\hline 105. & P. orientalis L. & + & & + & + & & & \\
\hline 106. & $\begin{array}{l}\text { Platycladus orientalis (L.) } \\
\text { Franco }\end{array}$ & + & + & + & + & & + & \\
\hline 107. & P.o. 'Globosa' & + & + & + & + & & & + \\
\hline 108. & $\begin{array}{l}\text { Populus alba L. (P. bolleana } \\
\text { Lauche) }\end{array}$ & + & + & + & & & + & \\
\hline 109. & P. $\mathrm{x}$ canescens (Ait.) Smith. & + & & & & & & \\
\hline 110. & $\begin{array}{l}P . \text { italica (DuRoi) Moench ( } P \text {. } \\
\text { pyramidalis Roz.) }\end{array}$ & + & & & + & & + & + \\
\hline 111. & P. nigra L. & + & & + & & & & \\
\hline 112. & P. simonii Carr. & + & & & + & & & \\
\hline 113. & P. tremula $\mathrm{L}$. & + & & & & & & \\
\hline 114. & $\begin{array}{l}\text { Prunus armeniaca (=Armeniaca } \\
\text { vulgaris Mill.) }\end{array}$ & + & + & + & + & + & & + \\
\hline 115. & $\begin{array}{l}\text { P. avium (L.) L. (=Cerasus } \\
\operatorname{avium}(\mathrm{L} .) \text { Moench.) (copra) }\end{array}$ & + & & & + & & & + \\
\hline 116. & $\begin{array}{l}\text { P. cerasus (Cerasus vulgaris } \\
\text { Mill.) }\end{array}$ & + & + & + & & & & + \\
\hline 117. & P. divaricata Ledeb. & + & + & + & + & & & \\
\hline 118. & P. domestica L. & + & & & & & & + \\
\hline 119. & $\begin{array}{l}\text { P. duclis (Mill.) D.A. Webb } \\
\text { (=Amygdalus communis L.) }\end{array}$ & + & & + & & & & \\
\hline 120. & P. pissardii Carriere & & + & & + & & & \\
\hline 121. & P. spinosa $\mathrm{L}$. & & & + & & & & \\
\hline 122. & Punica granatum L. & & & & + & & & \\
\hline 123. & Pyracantha coccinea Roem. & + & + & & & & & \\
\hline 124. & Pyrus communis L. & + & + & + & & & & + \\
\hline 125. & P. elaeagrifolia Pall. & + & & & & + & & + \\
\hline
\end{tabular}


продолжение табл.

\begin{tabular}{|c|c|c|c|c|c|c|c|c|}
\hline 126. & Quercus ilex L. & + & & & & & & \\
\hline 127. & Quercus pubescens Willd. & + & & & & & & \\
\hline 128. & Ribes aureum Pursh. & + & & & & & & \\
\hline 129. & Robinia pseudoacacia $\mathrm{L}$. & + & + & + & + & + & + & + \\
\hline 130. & R.p. 'Umbraculifera' & + & & + & & & & + \\
\hline 131. & R. viscose Vent. & + & & & & & & \\
\hline 132. & Rosa corymbifera Borkh. & + & & + & & + & & + \\
\hline 133. & Rosa sp. sp. & + & + & & + & & & \\
\hline 134. & Rosmarinus officinalis L. & & + & & & & & \\
\hline 135. & Salix aegyptiaca $\mathrm{L}$. & + & & & & & & \\
\hline 136. & S. alba L. & + & & + & & & & \\
\hline 137. & S. babylonica L. & + & & + & + & & + & + \\
\hline 138. & S. cinerea L. & + & & & & & & \\
\hline 139. & $\begin{array}{l}\text { S. matsudana Koidz. x } S . \\
\text { babylonica L. }\end{array}$ & & + & & & & & \\
\hline 140. & $\begin{array}{l}\text { Styphnolobium japonicum (L.) } \\
\text { Schott (Sophora japonica L.) }\end{array}$ & + & + & & + & + & & \\
\hline 141. & Sorbus domestica L. & & & + & & & & \\
\hline 142. & S. torminalis (L.) Crantz & & & & + & & & \\
\hline 143. & Spartium junceum $\mathrm{L}$. & + & & & & & & \\
\hline 144. & Spiraea $\mathrm{x}$ bumalda Burv. & + & & & . & & & \\
\hline 145. & S. cantoniensis Lour. & & & & + & & & \\
\hline 146. & S. x vanhouttei (Briot) Zab. & & + & & + & & + & + \\
\hline 147. & $\begin{array}{l}\text { Symphoricarpus albus (L.) } \\
\text { Blake }\end{array}$ & + & & & & & & \\
\hline 148. & Syringa vulgaris $\mathrm{L}$. & + & & + & & & + & \\
\hline 149. & Tamarix ramosissima Ledeb. & + & & + & + & & & \\
\hline 150. & T. tetrandra Pall. ex M. Bieb. & + & + & + & & & & \\
\hline 151. & Taxus baccata $\mathrm{L}$. & + & & & + & & & \\
\hline 152. & Thuja occidentalis `Aurea' & & + & & & & & \\
\hline 153. & T. o. 'Columna' & & + & & & & & \\
\hline 154. & Tilia dasystila Steven & & & & + & & & \\
\hline 155. & Ulmus minor Mill. & + & & + & & + & & + \\
\hline 156. & U. laevis Pall. & + & & + & & & & \\
\hline 157. & U. pumila $\mathrm{L}$. & + & + & & & + & & \\
\hline 158. & Viburnum lantana $\mathrm{L}$. & & + & & & & & \\
\hline 159. & V. opulus L. & + & & + & & & & \\
\hline 160. & V.o. 'Roseum` & + & & & & & & \\
\hline 161. & V. tinus L. & & + & & + & & & \\
\hline 162. & Vinca major L. & & + & & & & & \\
\hline 163. & V.m. 'Aureo-variegata` & & + & & & & & \\
\hline 164. & Vitis vinifera $\mathrm{L}$. & + & & + & + & + & & + \\
\hline 165. & Weigela sp. & & + & & & & & \\
\hline 166. & Wisteria sinensis (Sims.) Sweet. & + & & & & & & \\
\hline 167. & Yucca filamentosa $\mathrm{L}$. & + & + & & & & & \\
\hline 168. & Y. flaccida `Major’ & + & & + & & & & \\
\hline \multirow[t]{2}{*}{169.} & Y. recurvifolia Salisb. & + & & + & & & & \\
\hline & Всего & 118 & 88 & 70 & 59 & 22 & 54 & 28 \\
\hline
\end{tabular}


Таким образом, самыми значимыми объектами зеленого строительства в Коктебеле являются парки нескольких рекреационных комплексов, а отсутствие «зелени» и «общественного сада», как и в начале прошлого века, по-прежнему остаются недостатком современного поселка.

В настоящее время Коктебель нуждается в изменении своей структуры. Во-первых, очевидна острая необходимость перенесения транспортной магистрали Феодосия-Судак из центра поселка в обход его с одновременной организацией пешеходной зоны по всему центру от турбазы «Приморье» до дворца культуры с обязательными зелеными «островками» в виде небольших скверов, тротуаров с аллеями и т. п. Установлено, что единственный большой парк в населенном пункте окажет меньшее положительное воздействие на его климат, чем несколько меньших зеленых массивов, но рационально размещенных и соединенных между собой озелененными улицами и бульварами. Известно, что наилучшим типом озеленения улицы является такое распределение зелени: стена здания - газонная полоса - ряд деревьев - тротуар - ряд деревьев - газонная полоса - мостовая. Конечно, такой порядок распределения зелени возможен только на самых широких улицах, но на каждой озеленяемой улице нужно стремиться максимально приблизиться к этой схеме (Троицкий, 1954). Таким образом, очевидна необходимость создания в Коктебеле небольшого по площади общественного парка, дендропарка и т. п., где легче переносится дневной зной, а также приятно отдыхать в вечернее время. Мы полностью согласимся с С.Я. Елпатьевским, что большие парки и пышные цветники не подходят Коктебелю, как и регулярные сады французского стиля не соответствуют, на наш взгляд, его образу. Однако тенистые природные «английские» парки в современном оформлении могут быть полезны во многих отношениях: эстетических, санитарно-гигиенических, культурно-просветительских и т. п. В таких парках целесообразно использовать деревья и кустарники природной флоры Крыма, особенно ксерофильные, чтобы избежать необходимости регулярного полива: фисташка туполистная, можжевельник высокий, боярышник восточный и др. (Потапенко, Каменских, 2003). Интродуценты здесь могут применяться ограниченно, цветочное оформление также быть незначительным. Полезными в озеленении будут деревья с раскидистой кроной, дающие тень: платаны, ленкоранская акация, софора, средиземноморские виды ясеня, кельрейтерия и др. Хвойные деревья (кедры, кипарисы, можжевельники и др.) придадут пейзажу средиземноморский колорит.

Очевидно, что Коктебель будет застраиваться и в дальнейшем. При современной застройке территории здания вплотную прилегают к автомагистралям, не оставляя места не только для деревьев, но даже для газонной полосы. Такую практику необходимо ликвидировать и применять научно обоснованный подход к планировке и организации улиц, где зеленые насаждения играют важную роль. В таких условиях воздействие зеленых насаждений на микроклимат поселка будет максимальным.

\section{Выводы}

1. Культивируемая дендрофлора поселка Коктебель представлена 169 видами и формами. В городском озеленении используется 118 (70\%), остальное видовое и формовое разнообразие приурочено к зеленым насаждениям рекреационных комплексов.

2. При выработке концепции озеленения поселка необходимо учитывать как ландшафтно-климатические, так и его культурно-исторические особенности. Небольшие (до 1 га) скверы, более или менее равномерно расположенные по его территории и зеленые улицы, соединяющие их, значительно повысят привлекательность Коктебеля.

3. При выборе ассортимента деревьев и кустарников максимально использовать аборигенные декоративные растения и наиболее близкие им (экологически и физиономически) виды и формы интродуцентов. 


\section{Список литературы}

1. Владимиров Е.И., Костенко Н.С. Парки // Курорт Коктебель / под ред. А.А. Вронского. Киев: Наук. думка, 1997. - С. 79-82.

2. Гостев Ф.В., Юскевич Н.Н. Проектирование садов и парков: Учебн. для техникумов. - М.: Стройиздат, 1991. - 340 с.

3. Елпатьевский С.Я. Крымские очерки. Год 1913. - Феодосия: Изд. дом «Коктебель», 1998. $-143 \mathrm{c}$.

4. Ена А.В. Природная флора Крымского полуострова. - Симферополь: Н. Оріанда, 2012. $232 \mathrm{c}$.

5. Жарков Е.И. Страна Коктебель. - Киев: Болеро, 2008. - 607 с.

6. Колосюк Е.С., Савушкина И.Г. Таксономическая структура дендрофлоры г. Белогорска // Перспективы интродукции декоративных растений в ботанических садах и дендропарках (к 10-летию Ботанического сада Крымского федерального университета имени В.И. Вернадского) / Мат-лы междунар. науч. конф. (23-26 сентября 2014, г. Симферополь). Симферополь: Крымский федеральный университет имени В.И. Вернадского, 2014. - С. 40-43.

7. Кохно М.А., Кузнецов С.І., Дорошенко О.К., Чуприна П.Я., Пасічний А.О. Дендрофлора міст півдня УРСР // Укр. Ботан. журн. - 1983. - Вип. 40. - № 5. - С. 12-14.

8. Купченко В.П. Труды и дни Максимилиана Волошина. Летопись жизни и творчества. С.-Пб.: Алтейя, 2002. - 511 с.

9. Кучерявый В.А. Зеленая зона города. - Киев: Наук. Думка, 1981. - 246 с.

10. Левичев И.В., Тимиргазин А.Д. Коктебель. Старый Крым. Новый крымский путеводитель. - Симферополь: СОНАТ, 2003. - 179 с.

11. Лесина Н.П. Планерское (Коктебель): путеводитель. - Симферополь: Таврия, 1980. - 112 c.

12. Лунц Л.Б. Городское зеленое строительство. - М.: Стройиздат, 1966. - 247 с.

13. Петков И.В. Турбаза «Приморье» - Киев: Мистецтво, 1979. - 24 с.

14. Танасийчук В.Н. Из Коктебельской сокровищницы // Наука и жизнь. - 1983. - № 1. - С. 134-141.

15. Потапенко И.Л., Каменских Л.Н. Декоративные деревья и кустарники аборигенной флоры Крыма в озеленении курортов Коктебель и Курортное // Экосистемы Крыма, их оптимизация и охрана: тематич. сб. науч. трудов / под ред. В.Г. Мишнева, А.Н. Олиферова. - Симферополь: Таврия, 2003. - Вып. 13. - С. 82-89.

16. Потапенко И.Л., Кузнецов С.И. Древесные растения в озеленении населенных пунктов восточного района Южного берега Крыма // Інтродукція рослин. - 2009. - № 1. - С. $63-$ 67.

17. Потапенко И.Л., Летухова В.Ю., Розенберг О.Г., Диордиенко Е.В. Декоративные древесные растения г. Феодосии // Ученые записки Таврического национального университета им. В.И. Вернадского. Серия "Биология, химия". - 2014. - Т. 27 (66). - № 5 (Спецвыпуск). - С. 119-132.

18. Потемкина Н.В., Романенко Н.П. Инвентаризация дендрофлоры парка им. Т.Г. Шевченко в г. Симферополе / Бюлл. ГНБС. - 2011. - Вып. 102. - С. 86-90.

19. Потемкина Н.В., Шевчук Н.В. Результаты изучения озеленения города Красноперекопска Республики Крым // Экосистемы. - 2015. - Вып. 2. - С. 74-81.

20. Репецкая А.И., Парфенова М.А. Сквер 70-летия Великой Отечественной войны (Севастополь): современное состояние и проектные предложения // Экосистемы. - 2015. - Вып. 1. - С. 41-52.

21. Улейская Л.И., Головнев И.И., Плугатарь С.Л., Герасимчук В.Н., Харченко А.Л., Головнева Е.Е. Современная оценка Приморского парка арборетума Никитского 
ботанического сада и предложения по его реконструкции // Бюлл. ГНБС. - 2014. - Вып. 111. - С. 26-38.

22. Танасийчук В.Н. Из Коктебельской сокровищницы // Наука и жизнь. - 1983. - № 1. - С. 134-141.

23. Троицкий Н.А. Влияние зелени на климат города // Известия Крымского отдела Географического общества Союза ССР. - 1954. - Вып. 3. - С. 21-31.

24. Фадеева Т.М., Шапошников А.К., Дидуленко А.И. Старый добрый Коктебель. Симферополь: Бизнес-Информ, 2004. - 328 с.

25. Шапошников А.К. Старый добрый болгарский Коктебель. - Симферополь: Изд. дом «Амена», 1999. - 294 с.

26. Czerepanov S.K. Vascular plants of Russia and adjacent states (the former USSR). New York: Cambridge University Press, 1995. 516 p.

\section{HISTORY AND PRESENT STATE OF GREENARY IN TOWNSHIP KOKTEBEL Potapenko I.L. \\ T.I. Vyazemsky Karadag Research Station - Nature Reserve of RAS, Feodosia, Russian Federation, E-mail: ira_potapenko@mail.ru}

A list of ornamental arboreal plants used in various objects of green building Koktebel is given, the history of their formation is studied as well. Particular attention we paid to the parks and green zones of major recreational facilities. The ways of optimization the green spaces for various applications are proposed.

Key words: ornamental arboreal plants; aspects of planting of greenery; township Koktebel; Southeast Crimea 